\title{
WEAR MECHANISMS AND SURFACE ENGINEERING OF FORMING TOOLS
}

\author{
OBRABNI MEHANIZMI IN INŽENIRING POVRŠINE \\ PREOBLIKOVALNIH ORODIJ
}

\author{
Bojan Podgornik, Vojteh Leskovšek \\ Institute of Metals and Technology, Lepi pot 11, 1000 Ljubljana, Slovenia \\ bojan.podgornik@imt.si \\ Prejem rokopisa - received: 2015-01-05; sprejem za objavo - accepted for publication: 2015-03-02
}

doi:10.17222/mit.2015.005

\begin{abstract}
The manufacturing of parts is faced with ever-increasing demands for higher strength (hardness) and toughness of the work material, as well as higher productivity and environmental concerns. At the same time, the quality requirements are high and will continue to grow in the future. This leads to restrictions in terms of the type and use of lubricants and especially to increased requirements relating to the wear and fatigue resistance of tools.

The main focus on improving the wear resistance and tribological properties of forming tools has mainly been on developing tool steels with an improved fracture toughness and then modifying the lubricants for better retention and permeability at the tool/work-piece contact area. Nevertheless, the wear resistance of forming tools can also be successfully improved by surface-engineering techniques. In recent years, hard coatings in particular have shown enormous potential for improving the tribological properties of contact surfaces.

This paper reviews the wear mechanisms encountered in forming processes, as well as various surface-engineering techniques designed to improve the wear resistance and the anti-sticking properties of forming tools. The possible benefits and restrictions of different surface-engineering techniques are presented for the example of sheet-metal forming, fine blanking and forging.

Keywords: surface engineering, forming, hard coatings, topography, friction, wear
\end{abstract}

Preoblikovalna industrija se spopada z nenehno naraščajočimi zahtevami po višji trdnosti (trdoti) in žilavosti preoblikovanih materialov, kakor tudi večji produktivnosti in skrbi za okolje. Istočasno se povečujejo zahteve po kvaliteti izdelkov, kjer predvsem kvaliteta površine postaja vedno bolj pomembna. To pomeni omejitve pri uporabi maziv ter seveda večje zahteve po obrabni odpornosti in vzdržljivosti preoblikovalnih orodij.

Do nedavnega je izboljševanje obrabne obstojnosti in triboloških lastnosti preoblikovalnih orodij temeljilo predvsem na razvoju bolj žilavih in čistejših orodnih jekel ter modifikaciji maziv z boljšimi mazalnimi lastnostmi. V zadnjih letih pa tudi na področju preoblikovalnih orodij tehnike inženiringa površin, še posebej nanos trdih zaščitnih prevlek, omogočajo nadaljnje izboljšanje triboloških lastnosti kontaktnih površin.

$\mathrm{V}$ prispevku so tako predstavljeni obrabni mehanizmi, ki so jim izpostavljena preoblikovalna orodja, kakor tudi različne tehnike inženiringa površine, namenjene izboljšanju obrabne obstojnosti in tornih lastnosti preoblikovalnih orodij. Problemi in prednosti uporabe inženiringa površine so poudarjene na primeru hladnega preoblikovanja pločevine, štancanja in kovanja.

Ključne besede: inženiring površin, preoblikovanje, trde prevleke, topografija, trenje, obraba

\section{INTRODUCTION}

The forming industry is confronted with ever-increasing demands to form low-weight, high- and ultra-highstrength materials, as well as with higher productivity and environmental concerns. ${ }^{1}$ Simultaneously, we are increasing the requirements on the quality of the formed parts, especially in terms of surface quality. ${ }^{2-4}$ All these lead to restrictions regarding the use of the type and quality of the lubricants and to increased demands on the wear and fatigue resistance of the tool.

The wear resistance and the efficiency of forming tools are limited for different reasons, including thermal and mechanical fatigue and cracking, erosion, corrosion, abrasive and adhesive wear, and galling. ${ }^{5,6}$ In addition to that, tool replacement and reconditioning often depends on the surface quality of the formed parts. ${ }^{3,7,8} \mathrm{~A}$ smooth, defect-free surface represents a competitive market advantage, but mostly it is more favourable contact conditions and a better wear resistance. The main obstacles to obtaining smooth surfaces are the increased surface roughness and the wear of the tool, especially the adhesive wear and the galling. ${ }^{9,10}$ On the other hand, tool wear and galling also lead to increased contact pressures and unstable friction in the forming process.

Traditionally, improving the tribological properties and the wear resistance of forming tools was mainly based on the increased cleanliness, hardness and fracture toughness of the tool steel, as well as on the better lubricity and stability of the forming lubricants. However, wear and galling resistance can also be very successfully reduced with a proper modification or surface engineering of the tool surface. ${ }^{2,11}$ Commonly applied surfaceengineering processes, found in many tool applications, are the thermo-chemical treatments, ranging from basic surface hardening and plasma nitriding to more recent processes of deep cryogenic treatment and laser-surface remelting. ${ }^{12-16}$ However, in the past two decades, surface coating processes are gaining an advantage, including PVD, CVD and PACVD techniques. Thin, hard coatings 
with excellent tribological properties, like TiN, TiAlN, $\mathrm{CrN}$, etc., have already outperformed and successfully replaced traditional high-speed steel tools in the majority of cutting operations. ${ }^{17,18}$ Despite this, the majority of forming tools are still uncoated. Besides the complex geometry, which makes it difficult to obtain uniform coating deposition, commercial hard wear-resistant coatings show a relatively high coefficient of friction and a high tendency for galling against typical formed materials. ${ }^{19-21}$ Typical tool steels also have a lower load-carrying capacity than high-speed steel, ceramics and hard metals. As such, tool steels do not provide sufficient support for very thin, hard and brittle coatings. However, in recent years a lot of new deposition methods and coating types have been developed, which show excellent adhesion, as well as mechanical and tribological properties..$^{22}$ In order to exploit the full potential of hard coatings in terms of improving the tribological properties of forming tools, coated surfaces must primarily be able to sustain high-impact dynamic loading without cracking, debonding or spallation. The improved load-carrying capacity of coated systems can be obtained by increasing the thickness of the coating, which is not easy to achieve due to the high residual stresses, by employing support layers, which increases costs, or through the most efficient duplex technique, combining a classic thermo-chemical treatment of the steel substrate and PVD or PACVD deposition of the protective coat ing. ${ }^{19,23,24}$

Another option for improving the tribological properties, mainly the friction behaviour of the forming tools, either coated or un-coated, is through a surface-roughness and topography optimization. Proper selection and preparation of the surface topography, using techniques like polishing, shot-peening and laser surface texturing, can greatly improve the performance and galling resistance of the forming tools, and thus reduce or even eliminate the need for lubrication. ${ }^{7,25,26}$

\section{WEAR MECHANISMS IN FORMING APPLICATIONS}

Different materials can be formed in a desired shape or product using different processes, like casting, metal forming and machining. Metal forming is further divided into rolling, drawing, extrusion, sheet-metal forming, die casting and forging. ${ }^{27}$ During forming the tool surface is subjected to a sliding contact with the formed material, to high contact stresses and often to elevated temperatures, which all lead to tool wear. The wear mechanisms that can be found in forming applications include abrasive and adhesive wear, mechanical and thermal fatigue, plastic deformation and corrosion. ${ }^{27,28}$ Certainly, different wear mechanisms require different properties of the tool material and especially of the tool surface. However, in general, the surface of the tool should be hard and should maintain this hardness at high temperatures to reduce the abrasive wear. Furthermore, the tool material should be tough in order to limit or reduce the fatigue and be heat resistant with a high thermal resistivity. Typical wear mechanisms found in different forming operations and being responsible for tool wear are summarized in Table 1.

\subsection{Cold forming}

In the case of cold forming the tool failure is caused by five main wear mechanisms, which are a consequence of the high contact pressure and the relative motion between the tool surface and the formed material (Figure 1). ${ }^{29}$ The main wear and damage mechanisms in cold forming are:

- abrasive wear

- adhesive wear

- low-cycle fatigue

- crack propagation

- plastic deformation

The most dominant wear mechanism, found in all cold-forming operations, is adhesive wear. However, normally more than just one wear mechanism takes place, often even all of them can be observed, which depends on the forming process and the work material. In the case of punching and fine blanking, characterized by sharp edges and high impact loads, adhesion is accompanied by fatigue and chipping, and for drawing and extrusion, with abrasive wear. On the other hand, in the cold forming of harder and thicker materials, abra-

Table 1: Wear mechanisms in forming processes

Tabela 1: Obrabni mehanizmi v preoblikovalnih procesih

\begin{tabular}{|c|c|c|c|c|c|c|c|}
\hline & abrasion & adhesion & $\begin{array}{c}\text { low cycle } \\
\text { fatigue }\end{array}$ & $\begin{array}{l}\text { high cycle } \\
\text { fatigue }\end{array}$ & $\begin{array}{l}\text { thermal* } \\
\text { fatigue }\end{array}$ & corrosion & $\begin{array}{c}\text { plastic } \\
\text { deformation }\end{array}$ \\
\hline Punching, Fine blanking & $\mathrm{x}$ & $\mathrm{x}$ & $\mathrm{x}$ & $\mathrm{x}$ & & & $\mathrm{x}$ \\
\hline Deep drawing & $\mathrm{x}$ & $\mathrm{x}$ & & & & & \\
\hline Sintering & $\mathrm{x}$ & $\mathrm{x}$ & & $\mathrm{x}$ & & & \\
\hline Rolling & $\mathrm{x}$ & $\mathrm{x}$ & $\mathrm{x}$ & $\mathrm{x}$ & $\mathrm{x}$ & $\mathrm{x}$ & $\mathrm{X}$ \\
\hline Extrusion Drawing & $\mathrm{x}$ & $\mathrm{x}$ & $\mathrm{x}$ & $\mathrm{x}$ & $\mathrm{X}$ & & $\mathrm{X}$ \\
\hline Forging & $\mathrm{X}$ & $\mathrm{X}$ & $\mathrm{x}$ & $\mathrm{x}$ & $\mathrm{x}$ & $\mathrm{X}$ & $\mathrm{x}$ \\
\hline Injection moulding & $\mathrm{x}$ & $\mathrm{x}$ & & & $\mathrm{x}$ & $\mathrm{x}$ & \\
\hline Die casting & $\mathrm{x}$ & $\mathrm{x}$ & & & $\mathrm{x}$ & $\mathrm{x}$ & \\
\hline
\end{tabular}

* valid for processes at elevated temperatures 

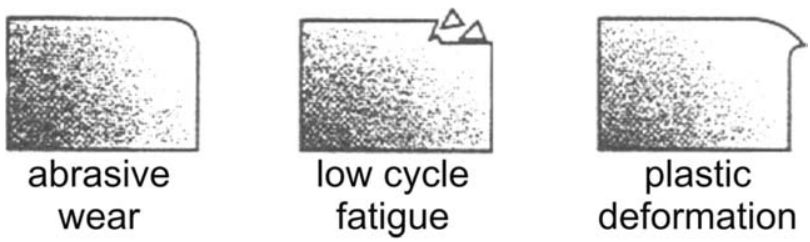
plastic deformation

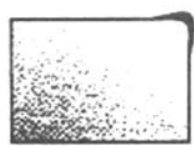

adhesive wear

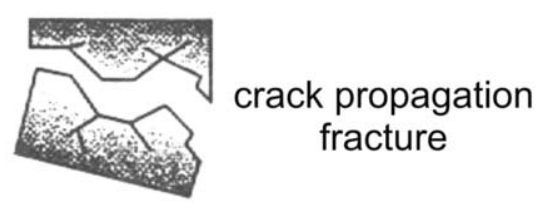

Figure 1: Wear mechanisms found in cold-forming processes ${ }^{29}$ Slika 1: Obrabni mehanizmi, značilni za procese hladnega preoblikovanja $^{29}$

sive wear and plastic deformation will dominate, while for softer materials it is adhesive wear, known also as galling.

Adhesive wear as the prevailing wear mechanism can be found in the cold forming of softer metals, like aluminium, titanium, copper, austenitic stainless steel, etc., and is especially critical in sheet-metal forming. The adhesive wear of forming tools is a result of local micro welds between the surface of the tool and the work-piece followed by the gradual transfer and accumulation of the work material on the tool surface, known also as galling. ${ }^{30}$ The transferred material causes unstable friction as well as scratching and a poor, uneven surface of the work-piece. Removal of the transferred work material can even cause abrasive wear of the tool surface. For good adhesive wear resistance the tool surface should be hard but with sufficient ductility, as smooth as possible and have low friction against the work material. In practice, adhesion or galling problems are mostly tackled by the application of different lubricants. However, the use of lubricants requires additional cleaning procedures and presents environmental concerns.

Abrasive wear dominates when forming hard materials or multiphase materials with hard particles (oxides, carbides, etc.) which scratch the tool surface and lead to tool wear. However, as already mentioned, abrasive wear can also be a result of adhesive wear. During forming the transferred and adhered work material becomes work hardened and when detached from the surface it represents a hard abrasive particle, which can cause threebody abrasive wear of the tool surface. Abrasive wear can be found in punching, fine blanking, drawing, extrusion and forging. The improved abrasive wear resistance of forming tools is mainly achieved by increasing the tool-surface hardness, either through thermo-chemical treatments or the deposition of hard, wear-resistant coatings.

Low-cycle fatigue is typical for punching, stamping and fine blanking, where the cutting edges are subjected to repeated high contact stresses. The repeated impact loading, sliding motion and local plastic deformation result in crack initiation and propagation, which finally leads to chipping. Due to this chipping the cutting edges become blunt and, consequently, this leads to increased stresses, unfavourable sliding conditions between the tool surface and the work-piece, and to adhesive wear. The resistance to low-cycle fatigue can be improved by increasing the ductility but without sacrificing the tool hardness.

In contrast to other wear mechanisms found in cold forming, crack propagation leads to instantaneous failure or even to the fracture of the tool, which is very hard to predict. Crack propagation is a consequence of stress concentrations, cracks initiation and the tensile stress field in the tool material. Since the majority of cracks start and propagate below the surface, the most important properties in terms of crack-propagation resistance are the properties of the base or substrate tool material. It has to possess high toughness, which on the other hand also means reduced hardness. Therefore, a suitable compromise between the increased toughness and the reduced tool hardness needs to be obtained.

Plastic deformation, caused by high contact pressures, is a common problem in many cold-forming operations. When the compressive stress exceeds the yield strength of the tool material, the tool geometry becomes distorted and this is often also coupled with imprints on the tool surface. The tool-geometry distortion means an incorrect shape of the formed part, while the presence of imprints leads to a poor surface quality. In terms of the resistance to plastic deformation, the most critical tool property is the hardness of the tool surface.

\subsection{Hot forming}

In hot-forming processes, including die casting, injection moulding and hot forging, the wear of the tool is caused by four types of loading: ${ }^{31}$

- thermal,

- mechanical,

- tribological,

- chemical.

Thermal loads are caused by repeated heat transfer from the work-piece and the repeated cyclic heating and cooling of the tool surface. High-temperature exposure leads to a reduced tool hardness as well as cyclic heating and cooling, leading to thermal fatigue. In the same way as in cold forming, also for hot forming, especially in the case of hot forging, mechanical loads may result in fatigue and plastic deformation. However, the tribological conditions in the case of hot forming are much more complex. Oxide layers formed on the work-piece surface are hard and brittle and as such result in the generation of hard, abrasive particles, which often cause abrasive wear of the tool surface. On the other hand, contact temperatures during hot forming often exceed $700{ }^{\circ} \mathrm{C}$, thus affecting the hardness and adhesive properties of the 


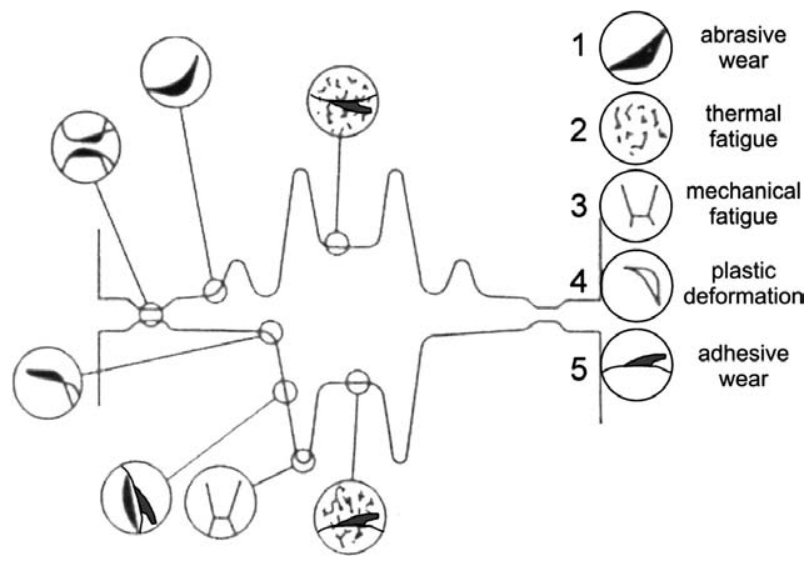

Figure 2: Typical wear mechanisms in hot forming ${ }^{32}$

Slika 2: Obrabni mehanizmi, prisotni pri vročem preoblikovanju ${ }^{32}$

contact surfaces. The higher is the temperature, the larger will be the drop in the surface hardness and more reactive is the surface, resulting in more intense abrasive wear and galling. The situation becomes even worse due to the constant flow of hot-work material into the contact with the tool surface. On the other hand, high temperatures also result in chemical loads on the tool, which may cause different chemical reactions on the tool surface, i.e., oxidation.

Different parts of hot-forming tools are subjected to different and quite specific combinations of loads and consequently display different wear mechanisms, as shown in Figure 2. ${ }^{32}$ The surfaces exposed to the highest temperature changes are subjected to thermal fatigue, and the surfaces with the highest stress concentrations, to mechanical fatigue. Furthermore, in processes with high thermal loads (die casting and injection moulding) an increased surface reactivity leads to adhesive wear and galling. However, in highly loaded tools for hot forging and extrusion, more than $70 \%$ of all tool failures are caused by abrasive wear of the tool surface.

\section{SURFACE ENGINEERING FOR IMPROVED TRIBOLOGICAL PROPERTIES OF FORMING TOOLS}

\subsection{Cold sheet-metal forming}

Failure and the replacement of tools for cold sheetmetal forming is mainly caused by adhesive wear and galling, which is followed by abrasive wear. An improvement in the abrasive wear is directly related to an increased hardness of the surface, achieved through different thermo-chemical treatments and hard-coating deposition techniques. ${ }^{12}$ Galling problems and unstable friction, on the other hand, are mainly addressed by the use of highly additivated and environmentally hazardous lubricants, which should provide proper lubrication between the tool and the work-piece surface. The improved tribological properties in sheet-metal forming processes can also be achieved through the proper surface engi- neering of the tool. ${ }^{2,33}$ The first group are the thermochemical treatments (nitriding, boriding, vanadizing), the second is surface texturing and the third is the deposition of low-friction coatings.

Investigations in the field of thermo-chemical treatments have shown that increased hardness of the surface and microstructure refinement obtained through a deep-cryogenic treatment can effectively improve the galling resistance of tool steel. ${ }^{16}$ On the other hand, the best results are obtained using plasma nitriding. ${ }^{25,34}$ The plasma nitriding of tool steel gives up to $40 \%$ lower friction against austenitic stainless steel and up to $50 \%$ better galling resistance, as compared to hardened tool steel, as shown in Figure 3. However, the selection of the proper plasma-nitriding parameters and post-treatment conditions is crucial. ${ }^{25,35}$ The presence of a compact $\gamma^{\prime}\left(\mathrm{Fe}_{4} \mathrm{~N}\right)$ compound layer may enhance the galling resistance against stainless steel, while a combination of porous $\varepsilon\left(\mathrm{Fe}_{2-3} \mathrm{~N}\right)$ and $\gamma^{\prime}$ compound layer and the use of a non-polished, nitrided surface have a detrimental effect (Figure 3).

More important than the selection of the thermo-chemical treatment is the proper preparation of the tool
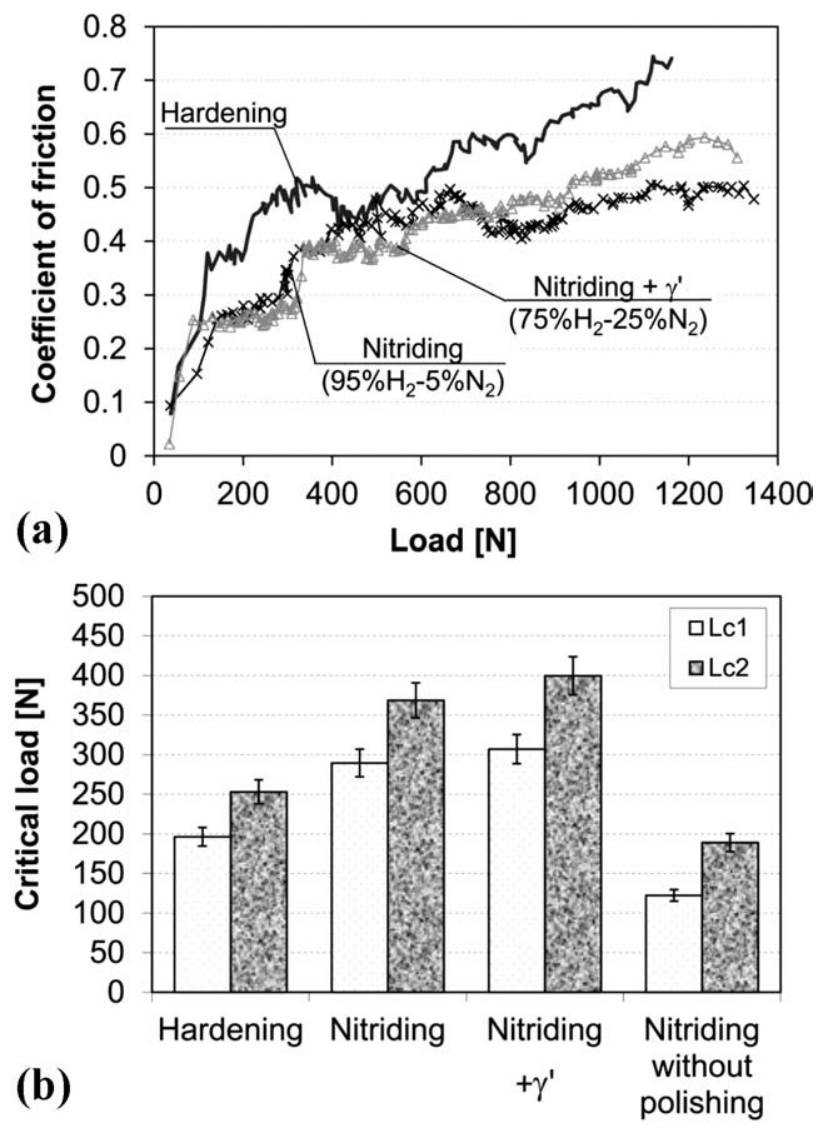

Figure 3: a) Coefficient of friction and b) critical loads for galling initiation $\left(L_{\mathrm{c} 1}\right)$ and transfer layer build up $\left(L_{\mathrm{c} 2}\right)$ for different surface treatments of tool steel ${ }^{35}$

Slika 3: a) Potek koeficienta trenja in b) kritična obremenitev začetka prenosa $\left(L_{\mathrm{c} 1}\right)$ ter tvorjenja plasti nerjavnega jekla $\left(L_{\mathrm{c} 2}\right) \mathrm{v}$ odvisnosti od kemo-termične priprave površine orodnega jekla ${ }^{35}$ 
surface. ${ }^{7,26}$ As shown in Figure 4, even with just simple polishing of the tool surface, a low and stable coefficient of friction can be achieved, and the galling resistance can be greatly improved. Rough surfaces $\left(R_{\mathrm{a}}>0.25 \mu \mathrm{m}\right)$ result in high and unstable friction, but above all in the almost immediate transfer of work material to the tool surface. By reducing the surface roughness below 0.05 $\mu \mathrm{m}$, low and stable friction and excellent galling resistance across a broad load range can be achieved, even with reduced lubrication, the use of less additivated lubricants or without any lubrication (Figure 4).

A microscopic analysis of the contact surfaces of the tools for cold forming has revealed that galling and the transfer of work material is initiated at scratches, irregularities and asperities on the tool surface, ${ }^{36}$ as shown in Figure 5a. During forming and load increases the transferred material becomes accumulated around the initial galling points, forming a thick, transferred layer on the tool surface (Figure 5b). Therefore, every imperfection on the tool surface represents a potential initial point for the beginning of the galling and the work-material transfer. Polishing the surface, on the other hand, removes and smoothens the scratches and imperfections caused during tool manufacturing, thus greatly reducing the risk of adhesive wear. In forming processes, where lubricants and lubrication cannot be eliminated, more
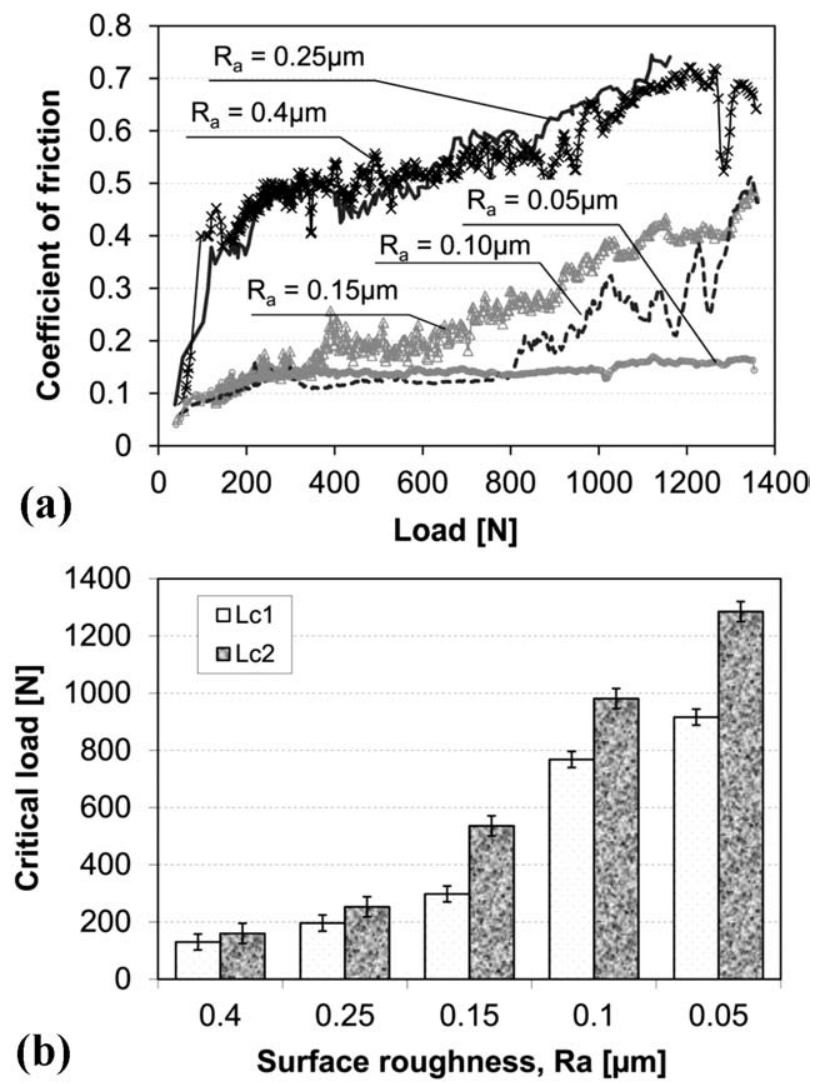

Figure 4: Effect of surface roughness on: a) the coefficient of friction and b) the critical loads for stainless-steel transfer ${ }^{7}$

Slika 4: Vpliv hrapavosti površine na: a) potek koeficienta trenja in b) kritično obremenitev prenosa nerjavnega jekla ${ }^{7}$
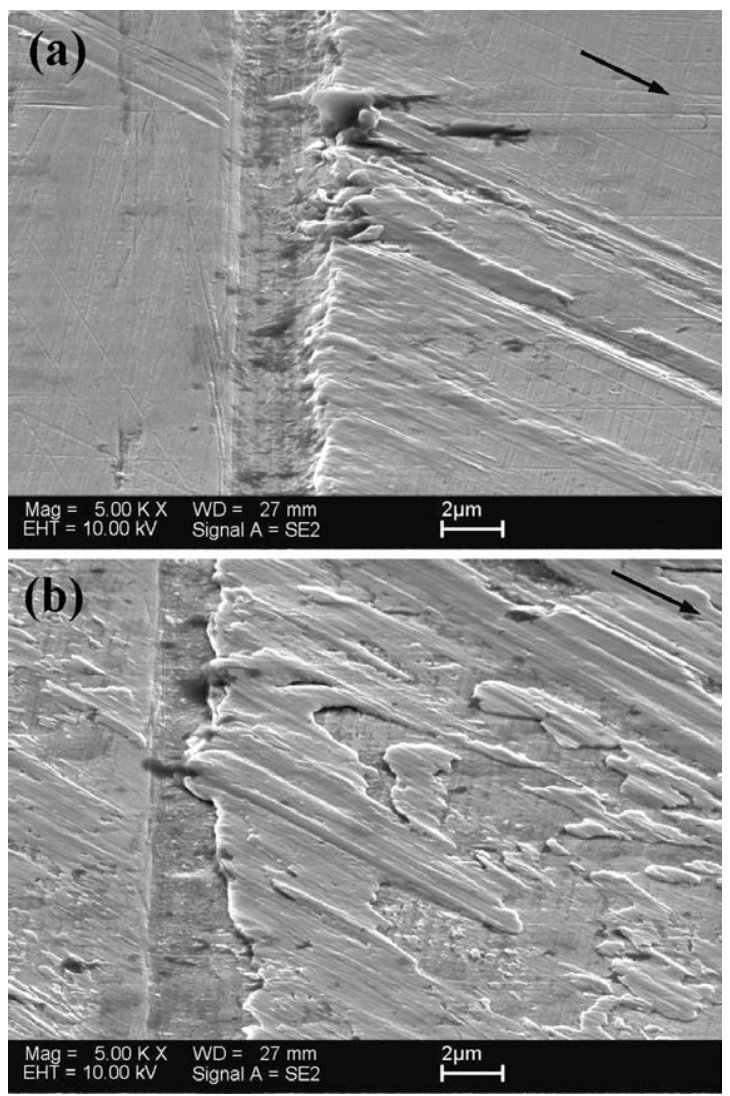

Figure 5: a) Beginning of galling and b) accumulation of thick transferred layer of work material on the tool surface

Slika 5: a) Začetek adhezije preoblikovanega materiala na površino orodja in b) akumulacija in tvorjenje plasti prenesenega materiala

favourable tribological properties and a reduced amount of lubricants can be achieved through the surface texturing. ${ }^{37-39}$ Surface structures in the form of channels or dimples with the proper size and density (Figure 6) may act as mini-reservoirs, which can effectively feed the lubricant into the contact and prevent, or at least reduce, galling. ${ }^{26}$

The third option for improving the tribological properties of tools for cold sheet-metal forming is the

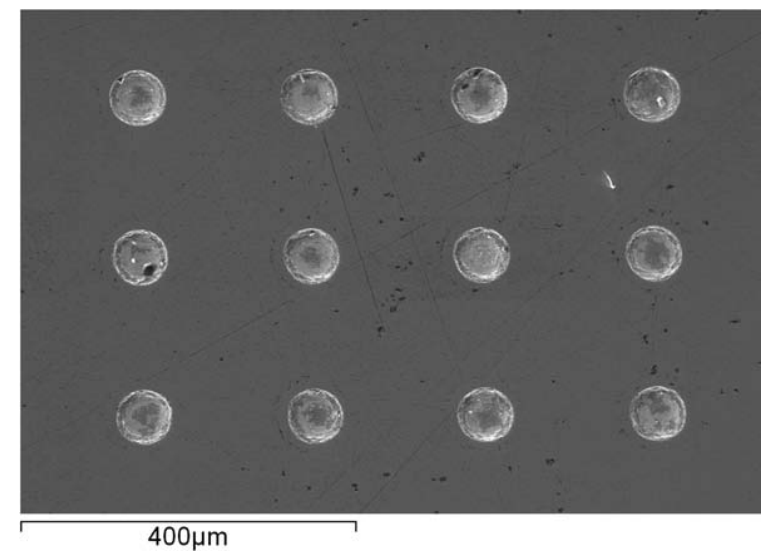

Figure 6: Surface-textured tool surface

Slika 6: Obličena kontaktna površina 
deposition of a hard protective coating. In the case of cutting tools, hard ceramic coatings, i.e., TiN, TiAlN, AlCrN, etc., successfully replace classic materials, giving a greatly improved abrasive wear resistance and productivity and, in some cases, even allowing for dry cutting. ${ }^{40}$ However, the requirements for the successful implementation of hard coatings on forming tools are much tougher and more complex. Besides the more complex geometry of forming tools and the limited load-carrying capacity of the tool-steel substrate, typical commercial hard coatings for cutting applications show a high friction and a strong tendency to pick up work material. Therefore, coating selection in the forming operations mainly depends on the material to be formed and the coating galling tendency against it. ${ }^{2,32,41}$

In the case of stainless steel a TiN coating gives a similar friction to un-coated cold-work tool steel, but almost instantaneous adhesion and galling. As shown in Figure 7, similar properties with a high galling tendency against stainless steel are also displayed by other hard ceramic coatings. On the other hand, carbon-based coatings, either amorphous diamond-like-carbon coatings (DLC) or metal-doped carbon-based coatings (W-C,
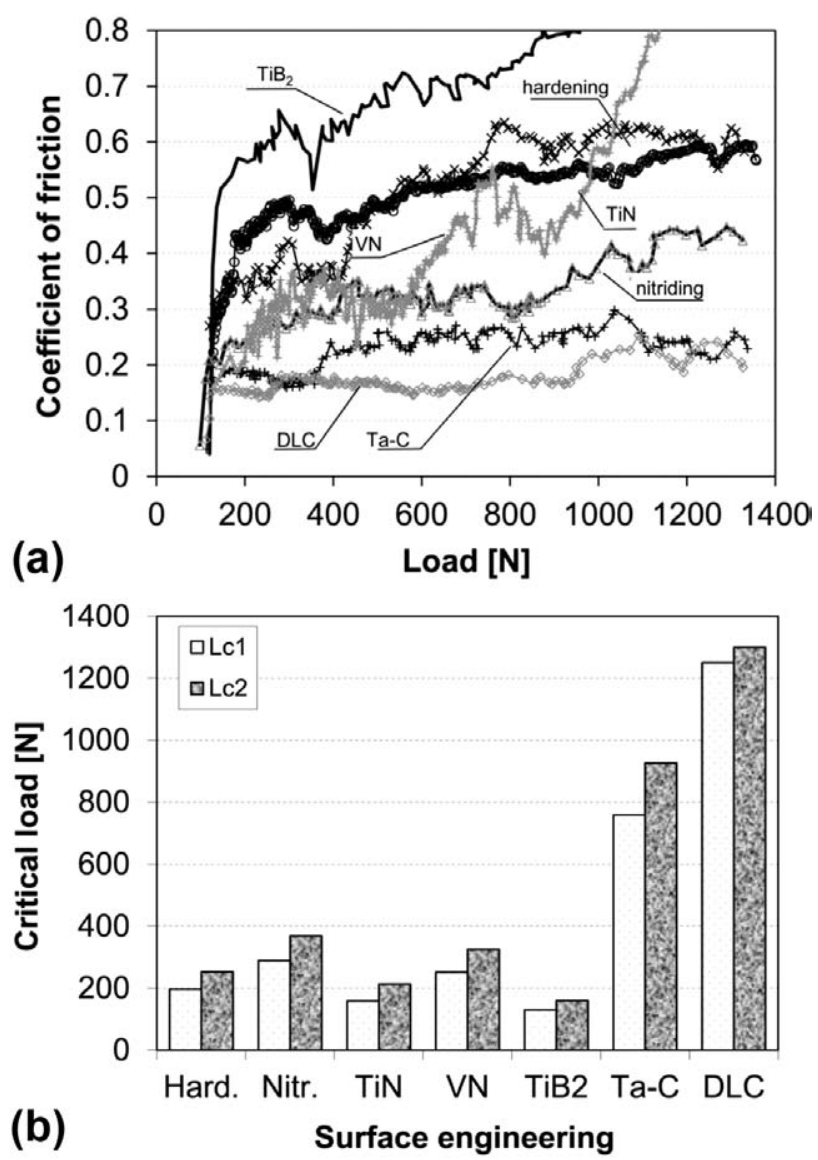

Figure 7: a) Coefficient of friction and b) critical loads for galling initiation and transfer-layer build up for different hard coatings tested against stainless steel ${ }^{35}$

Slika 7: a) Potek koeficienta trenja in b) kritične obremenitve prenosa nerjavnega jekla pri suhem drsnem kontaktu različnih prevlek ${ }^{35}$
Ta-C, etc.) provide low and stable friction, even under dry-sliding conditions. ${ }^{42}$ At the same time, DLC coatings considerably increase the critical loads for galling initiation and transfer-layer build up when it comes to the forming of stainless steel (Figure 7b).

Although polishing of the contact surface greatly improves the tribological properties of tool steel, highly additivated lubricants are still required to prevent galling and transfer-layer build up when forming stainless steel. Switching to pure base oil does not allow more than 10 forming cycles, which are more or less limited to low loads and low deformation rates before adhesion and galling take place (Figure 8a). However, with the application of DLC coatings we can effectively prevent adhesive wear and provide a stable tribological contact with a low coefficient of friction $(\approx 0.1)$ with a more environmentally friendly base lubricant without any additives, ${ }^{7}$ as shown in Figure $\mathbf{8 b}$.

When forming aluminium and aluminium alloys, galling and adhesion to hardened tool steel take place immediately and at very low loads if the contact is not
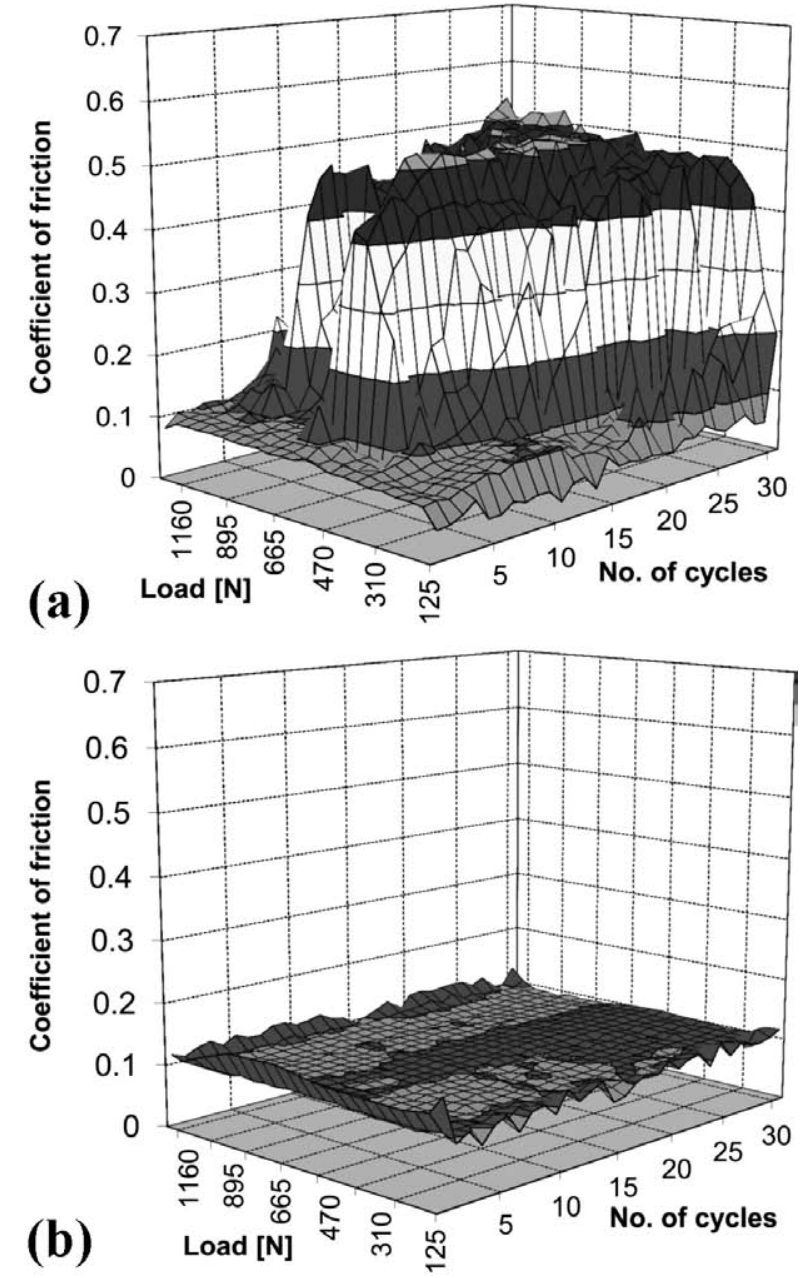

Figure 8: Friction maps for: a) polished tool steel and b) DLC-coated surface-lubricated with pure PAO8 base oil ${ }^{7}$

Slika 8: Karte koeficienta trenja za: a) polirano orodno jeklo in b) površino, prekrito z DLC-prevleko; bazno olje PAO8 ${ }^{7}$ 
lubricated. Even through surface engineering (polishing, nitriding, hard coating) galling resistance cannot be improved to any great extent. However, the proper selection of surface-engineering technique affects the coefficient of friction and the critical loads for aluminium transfer-layer build up. In contrast to stainless steel, DLC coatings show no beneficial effect when it comes to forming aluminium alloys. However, the galling performance of DLC coatings also depends on the coating and the aluminium-alloy type. ${ }^{43-45}$ In the case of aluminium alloys a certain reduction in the coefficient of friction and increased critical loads for the transfer-layer build up can be expected with the application of nitride-type coatings (TiN, VN, CrN, etc.) and by nitriding the tool-steel surface, as shown in Figure 9a. Even smaller differences between different surface-engineering techniques in terms of galling resistance are found for titanium and titanium alloys, where plasma nitriding shows the greatest potential (Figure 9b).

\subsection{Punching and fine blanking}

In punching and fine blanking the cutting elements of the tool are subjected to high impact loads as well as to a sliding contact. Impact loads lead to low-cycle fatigue and the chipping of the cutting edges, while sliding
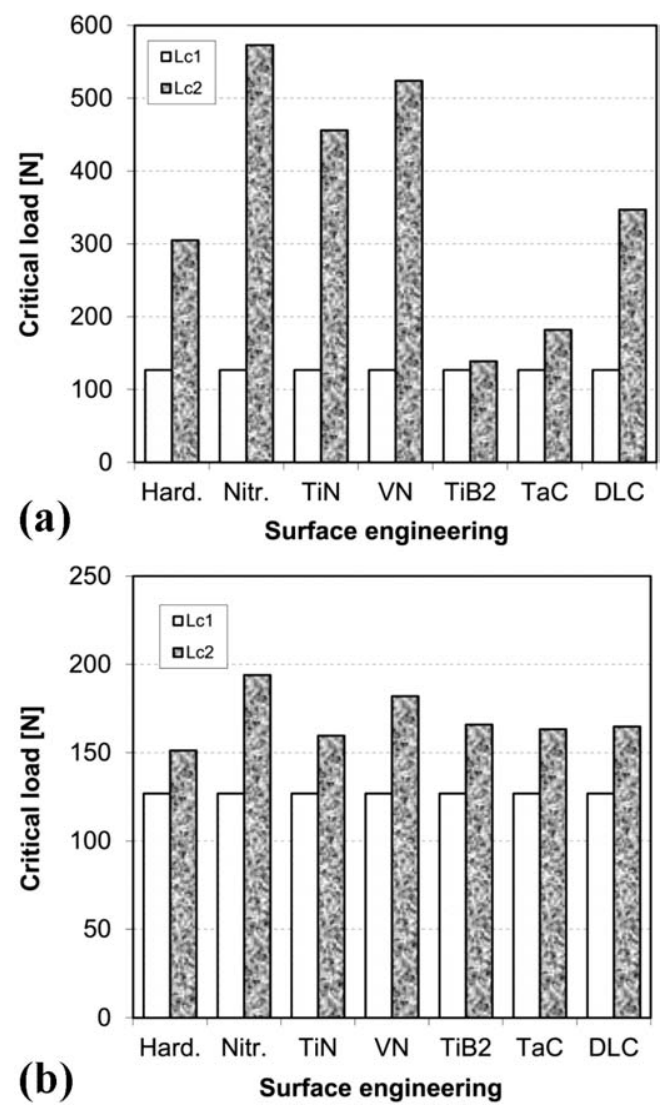

Figure 9: Critical loads for galling against: a) aluminium alloy and b) titanium alloy ${ }^{35}$

Slika 9: Kritične obremenitve prenosa materiala za: a) aluminijevo in b) titanovo zlitino ${ }^{35}$ against steel sheet material causes galling and abrasive wear. An improvement in the abrasive wear resistance as well as in the galling resistance can be achieved through the deposition of hard coatings. At the same time, a substrate material with a high toughness is required in order to postpone the low-cycle fatigue and the chipping of the cutting edge. This, on the other hand, means insufficient load-carrying capacity, which often results in coating cracking and delamination ${ }^{46}$. And the harder is the coating, the higher is the risk of coating failure. For the coating to show its full potential in reducing friction and increasing surface wear resistance, we primarily have to provide sufficient load-carrying capacity for the substrate. This can be achieved by combining a thermochemical treatment of the substrate and hard-coating deposition, called a duplex treatment. ${ }^{19,47}$ As shown in Figure 10a, by plasma nitriding the load-carrying capacity of the tool steel can be increased by up to three times. However, improper preparation of the substrate (the presence of a $\gamma^{\prime}$ compound layer, a high roughness) or insufficient coating adhesion ( $\mathrm{TaC}$ ) will lead to immediate flaking of the coating (Figure 10b), regardless of the substrate's properties.

Besides the load-carrying capacity, the tribological properties and the resistance of the coated surfaces to
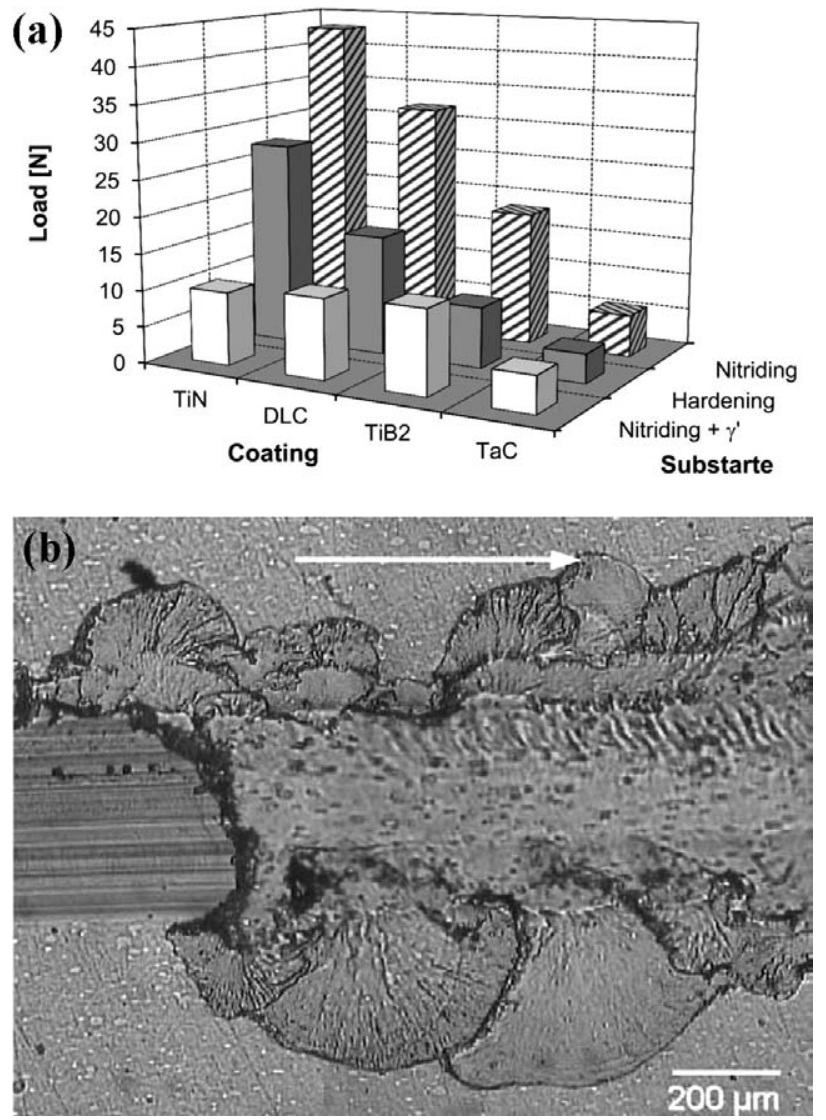

Figure 10: a) Effect of substrate treatment on the load-carrying capacity of coated tool steel and b) flaking of the TaC coating ${ }^{19}$

Slika 10: a) Vpliv kemo-termične priprave podlage na nosilnost oplaščenih površin in b) luščenje prevleke $\mathrm{TaC}^{19}$ 
dynamic loading also depend on the coating type and the properties of the substrate material, ${ }^{48}$ as shown in Figure 11. The best resistance is achieved by multilayer coatings composed of a base, load-carrying ceramic layer (TiAlN, CrN, etc.) and top, low-friction layer (DLC, $\mathrm{Me}-\mathrm{C}: \mathrm{H}, \mathrm{MoS}_{2}$, etc.). Multilayer coatings are followed by gradient coatings (i.e., TiCN), while the lowest resistance to dynamic loading is displayed by monolayer coatings of $\mathrm{TiN}, \mathrm{AlCrN}$, etc. (Figure 11). In terms of substrate material, due to the poor adhesion and a high flaking tendency, tungsten carbide is not the most suitable for coated tools subjected to high dynamic impact loading. The best substrate material, regardless of the coating used, is fine-grained, micro-clean tool steels produced by powder metallurgy (P/M) processes. ${ }^{49,50}$ In order to provide a high load-carrying capacity combined with a superior impact, a wear-resistant tool-steel substrate should have a hardness of at least $64-65 \mathrm{HRc}$ and a fracture toughness above $12 \mathrm{MPa} \mathrm{m}^{1 / 2} .^{51}$ Although plasma nitriding provides the highest static load support, its negative effect on the surface ductility greatly reduces the resistance of the coated surface on the crack initiation and propagation, ${ }^{52,53}$ as shown in Figure 12.

The purpose of hard coatings in punching and fine blanking is not only to increase the wear resistance of the
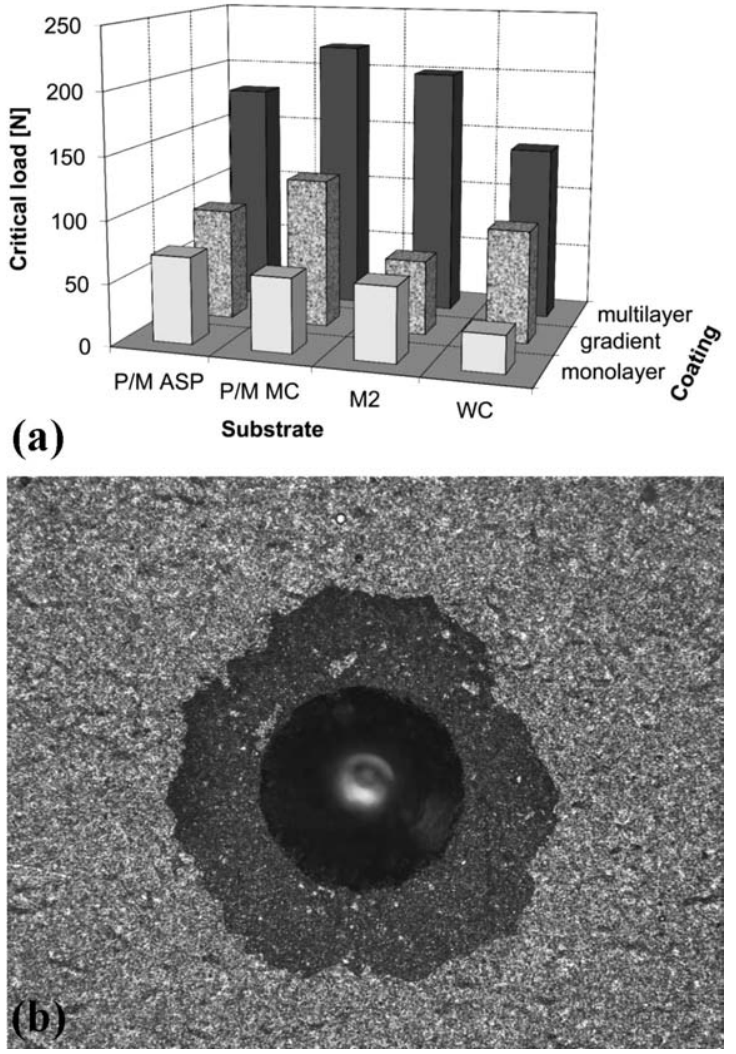

Figure 11: a) Effect of substrate material and coating type on the load-carrying capacity and b) example of poor coating adhesion in the case of tungsten carbide substrate ${ }^{48}$

Slika 11: a) Vpliv materiala podlage in tipa prevleke na nosilnost oplaščene površine ter b) primer neustrezne oprijemljivosti na podlago karbidne trdine $\mathrm{e}^{48}$

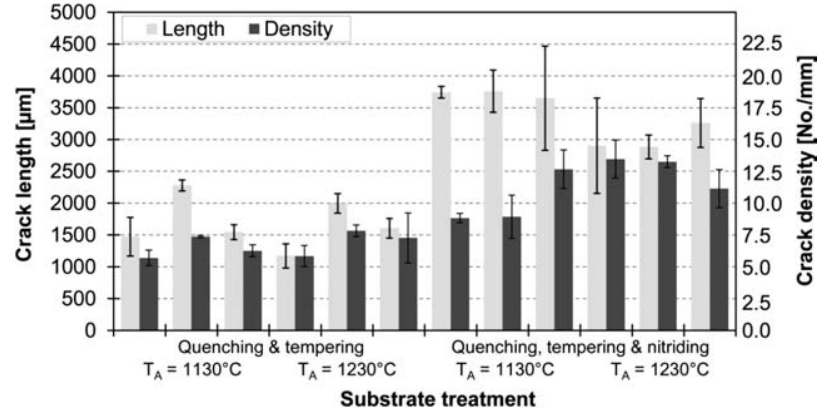

Figure 12: Effect of substrate treatment type on the crack length and the density in a gradient TiCN coating deposited on fine-grained micro-clean P/M tool steel and subjected to a sliding contact at 3500

Slika 12: Vpliv postopka priprave podlage na dolžino in gostoto razpok $\mathrm{v}$ gradientni TiCN-prevleki, naneseni na finozrnato orodno jeklo $\mathrm{P} / \mathrm{M}$ in izpostavljeno drsnemu kontaktu pri $3500 \mathrm{~N}^{52}$

tool but also to reduce or even eliminate the lubrication. As shown in Figure 13, regardless of the substrate material used, the lowest coefficient of friction $(\approx 0.15)$ and the highest potential are shown by carbon-based or diamond-like-carbon coatings (DLC). On the other hand, harder ceramic coatings, especially nitride-type multilayer coatings, display a much higher friction $(>0.3)$, but when deposited on a suitable substrate up to 10 times less wear (Figure 13).

Experiments with coated punching and fine-blanking tools have shown that although coatings can greatly
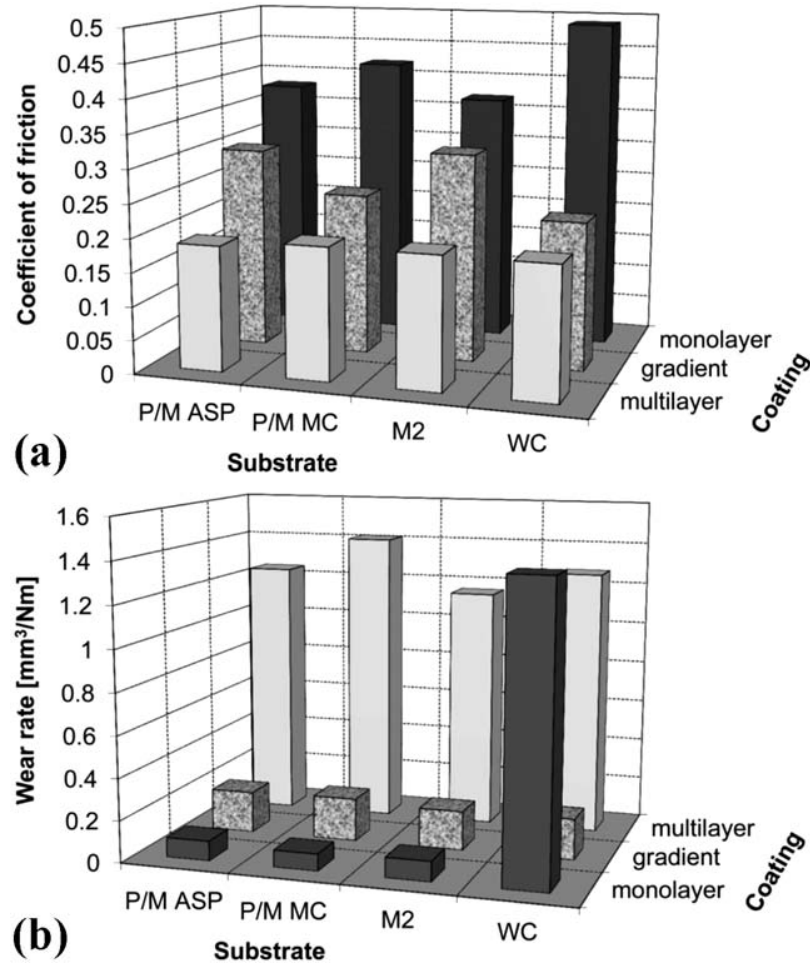

Figure 13: a) Effect of substrate material and coating type on: a) coefficient of friction and b) wear rate in a dry-sliding contact ${ }^{48}$

Slika 13: a) Vpliv materiala podlage in tipa prevleke na: a) koeficient trenja in b) stopnjo obrabe pri suhem drsnem kontaktu ${ }^{48}$ 
increase the tools' performance and wear resistance, neither coating group and type allow the complete elimination of lubrication. ${ }^{48,54}$ In the case of hard ceramic coatings, high friction leads to the adhesion of the work material to the tool surface and consequently for up to three times higher extraction forces and even up to ten times higher punching forces, which then lead to coating cracking and flaking (Figure 14). On the other hand, for DLC coatings, although initially reducing the punching forces, a high coating-wear rate in just a few strokes leads to failure of the cutting elements. However, the combination of minimum lubrication, a suitable fine-grained-steel substrate and its heat treatment, and a hard, wear-resistant coating can result in the greatly improved resistance of both sliding surfaces and cutting edges of the punching and fine blanking tools.

\subsection{Hot forging}

Tools for hot forging are exposed to the widest and most demanding loading and contact conditions, which result in the most severe wear of the tool surface. Besides the adhesive and abrasive wear, the contact surfaces are exposed to mechanical and thermal fatigue, as well as to plastic deformation. ${ }^{31,46}$ Traditionally, forging dies are subjected to different thermo-chemical treatments, mostly to nitriding in order to improve their
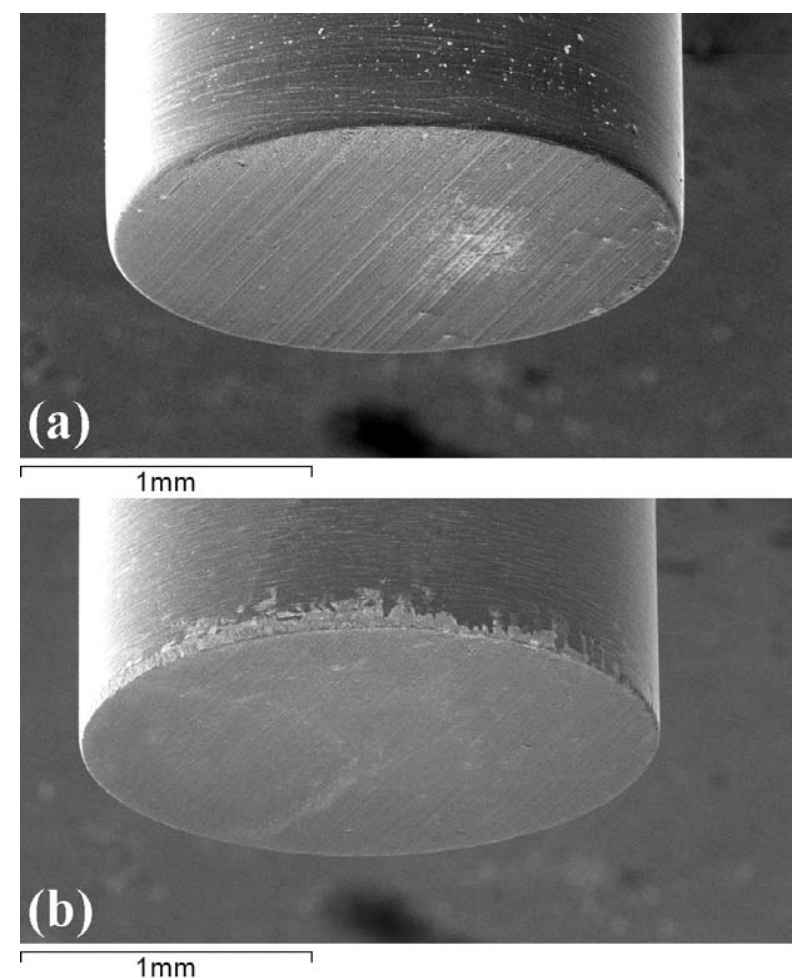

Figure 14: Contact surface of punching tool coated with monolayer AlCrN coating after 4000 strokes: a) fine-grained micro-clean P/M tool steel substrate and b) WC substrate ${ }^{48}$

Slika 14: Površina štancnega noža, prekritega z AlCrN-prevleko, po 4000 udarcih; podlaga iz: a) visokokvalitetnega jekla $\mathrm{P} / \mathrm{M}$ in b) karbidne trdine ${ }^{48}$ wear resistance and lifetime. ${ }^{55}$ However, due to the very high contact temperatures, all these treatments have only a limited effect. ${ }^{46}$ On the other hand, investigations with hard coatings, including $\mathrm{TiN}, \mathrm{TiCN}, \mathrm{CrN}, \mathrm{TiB}_{2}$, etc., show very promising results. ${ }^{56,57}$ Coatings prevent thermal fatigue and the formation of intermetallic alloys on the tool surface, while at the same time they protect the substrate material from thermal shocks and softening. Furthermore, with a high hardness, which can be maintained even at very high temperatures, coatings also improve the tool's abrasive and erosive wear resistance.

As shown in Figure 15, the deposition of gradient or multilayer coatings can significantly improve the wear resistance of hot-forging die inserts. When they are only nitride, the surface hardness of the inserts will drop by more than $15 \%$ in less than 15000 strokes, eventually resulting in severe plastic deformation and wear of the inserts. On the other hand, a combination of plasma nitriding and a hard PACVD coating was found to prevent a drop in the surface hardness and almost eliminated the wear of the contact surfaces. ${ }^{56}$ As shown in Figure 15, even after about 15000 strokes the coated inserts were able to maintain their initial geometry.

Although the coatings have exceptional thermal and anti-wear properties, coating deposition on an improperly prepared substrate will lead to a deterioration rather than an improvement in the performance of forging dies. Insufficient hardness and a too rough substrate will cause coating cracking and delamination (Figure 16a), which even accelerates the abrasive wear of the die. Furthermore, the use of hardened hot-work tool steel with a coarse microstructure greatly increases the likelihood of cracks initiation and propagation, thus reducing the tool's fatigue resistance. ${ }^{5}$ As in the case of punching tools, the best results are obtained through duplex technology, combining plasma nitriding of the tool-steel substrate and PVD or PACVD coating deposition. ${ }^{57,58}$ However, besides the substrate hardness, a very important substrate property is its fracture toughness. ${ }^{59} \mathrm{~A}$ dense

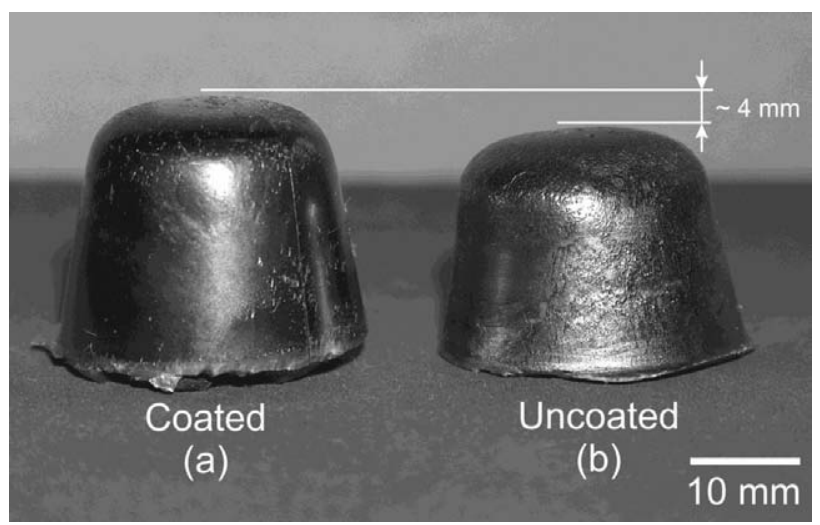

Figure 15: Forging die insert after 13500 strokes: a) Duplex - TiCN + nitriding, b) only nitrided ${ }^{56}$

Slika 15: Vložek kovaškega utopa po 13500 udarcih: a) Duplex $\mathrm{TiCN}+$ nitriranje, b) nitriran ${ }^{56}$ 

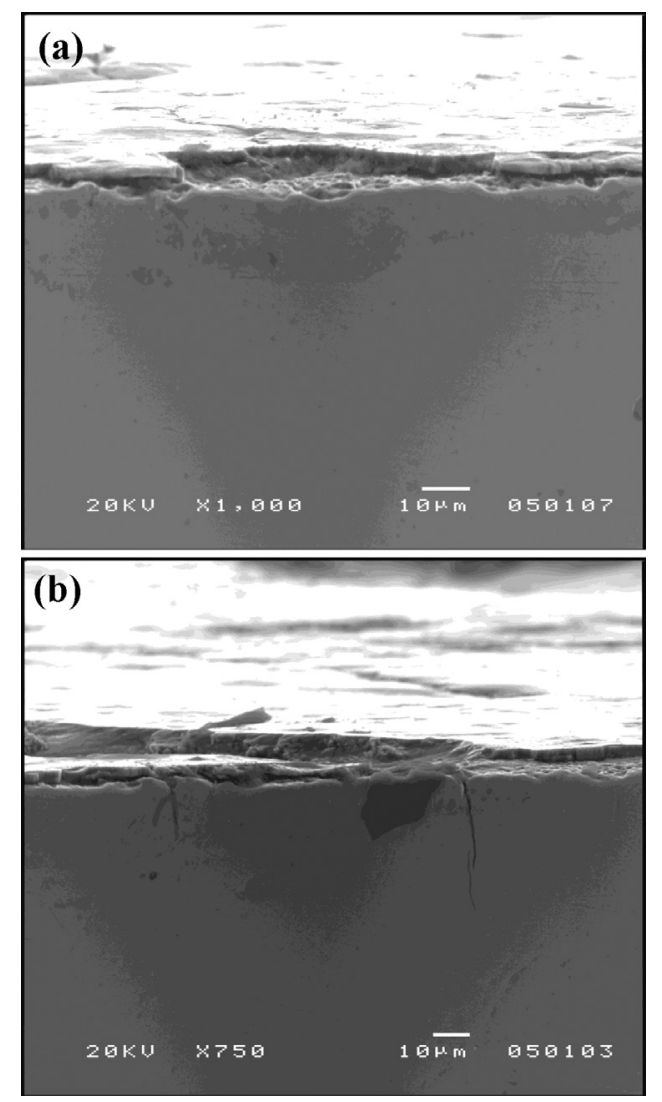

Figure 16: Failure of the coated die insert: a) flaking and b) crack initiation and propagation

Slika 16: Poškodba oplaščenega kovaškega orodja: a) luščenje in b) nastanek ter širjenje razpok

$\gamma$ ' compound layer may act as an additional support interlayer, but its brittleness leads to a reduced coatingcracking resistance as soon as the substrate core hardness is reduced below $50 \mathrm{HRc}$. Even for a compoundlayer-free nitrided substrate a high core-hardness level is the main requirement in providing good load support, but it needs to be supported by a sufficient fracture-toughness level ${ }^{53}$ (Figure 17).

\section{CONCLUSIONS}

The first step in improving the tribological properties and galling resistance of forming tolls is reducing the surface roughness. Surface polishing smoothens and removes the surface irregularities and thus eliminates potential spots for galling initiation. Increasing surface hardness or the deposition of a hard coating, although improving the abrasive wear resistance, exaggerates the effect of the surface roughness.

In cold sheet-metal forming the main wear mechanism responsible for tool failure is adhesive wear or galling. The selection of a surface-engineering technique aimed at improving the anti-galling properties mainly depends on the material to be formed. In the case of stainless steel, low and stable friction as well as complete protection of the tool surface against galling under

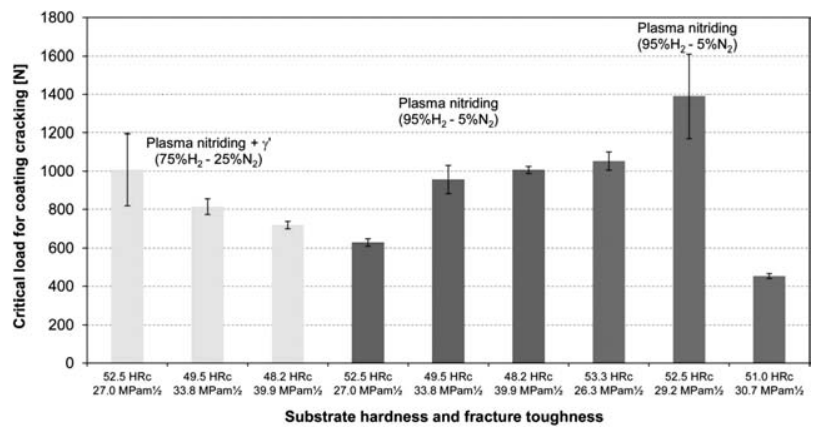

Figure 17: Effect of substrate hardness and fracture toughness on the load-carrying capacity of $\mathrm{TiN} / \mathrm{TiB}_{2}$-coated hot-work tool steel ${ }^{53}$

Slika 17: Vpliv trdote in lomne žilavosti orodnega jekla za delo v vročem na kritično obremenitev nastanka razpok v TiN/TiB 2 -prevleki ${ }^{53}$

high loads and boundary lubrication is provided by carbon-based or diamond-like-carbon coatings. Nitridetype coatings, on the other hand, are more suitable for the cold forming of aluminium and aluminium alloys, and plasma-nitrided tool steel for titanium alloys.

For the successful use of hard coatings and improved tool performance in punching and fine blanking operations, first of all the substrate needs to have a sufficient load-carrying capacity. Besides that, a high hardness should be coupled with a sufficient fracture toughness. The best results are obtained when using multilayer coatings on fine-grained micro-clean $\mathrm{P} / \mathrm{M}$ tool steels. P/M tool steels give good impact and fatigue resistance, while an optimal thermo-chemical treatment provides a superior load support. Although the complete elimination of lubrication in punching and fine blanking is not yet possible, the superior wear resistance and friction performance of hard coatings allow a reduction in the lubrication quantity and the amount of additives.

Due to the combined mechanical and thermal loads of hot-forging dies the proper selection and optimal parameters of substrate thermo-chemical treatment are crucial for the proper performance of the coated tools. Instead of the expected improvement an improper combination of substrate hardness and toughness can lead to increased wear and accelerated crack initiation and propagation. The highest potential for improving the performance of hot-forging dies is shown by the combination of a plasma-nitrided tool-steel substrate coated with a multilayer nano-composite coating. However, before the coating the substrate needs to be polished and increased substrate hardness combined with sufficient fracture toughness.

\section{REFERENCES}

${ }^{1}$ P. Groche, M. Christiany, Evaluation of the potential of tool materials for the cold forming of advanced high strength steels, Wear, 302 (2013), 1279-1285, doi:10.1016/j.wear.2013.01.001

${ }^{2}$ B. Podgornik, S. Hogmark, Surface modification to improve friction and galling properties of forming tools, Journal of Materials Processing Technology, 174 (2006), 334-341, doi:10.1016/j.jmatprotec. 2006.01.016 
${ }^{3}$ C. Mitterer, F. Holler, C. Lugmair, R. Nobauer, R. Kullmer, C. Teichert, Optimization of plasma-assisted chemical vapour deposition hard coatings for their application in aluminium die-casting, Surface and Coatings Technology, 142-144 (2001), 1005-1011, doi:10.1016/ S0257-8972(01)01065-9

${ }^{4}$ A. Attanasio, E. Ceretti, C. Giardini, L. Mazzoni, Asymmetric two points incremental forming: Improving surface quality and geometric accuracy by tool path optimization, Journal of Materials Processing Technology, 197 (2008), 59-67, doi:10.1016/j.jmatprotec.2007. 05.053

${ }^{5}$ A. Persson, J. Bergstrom, S. Hogmark, Influence of surface engineering on the performance of tool steels for die casting, $6^{\text {th }}$ International Tooling Conference, Karlstad, Sweden, 2002, 841-854

${ }^{6}$ R. Jervis, B. Johnson, L. A. Norstrom, O. Sandberg, Properties profile of a new presswork tool steel, International Conference on Tooling Materials, Interlaken, Switzerland, 1992, 49-64

B. Podgornik, S. Hogmark, O. Sandberg, Influence of surface roughness and coating type on the galling properties of coated forming tool steel, Surface and Coatings Technology, 184 (2004), 338-348, doi:10.1016/j.surfcoat.2003.11.002

${ }^{8}$ D. Wang, H. Li, H. Yang, J. Ma, G. Li, Tribological evaluation of surface modified $\mathrm{H} 13$ tool steel in warm forming of Ti-6Al-4V titanium alloy sheet, Chinese Journal of Aeronautics, 27 (2014), 1002-1009, doi:10.1016/j.cja.2014.03.030

${ }^{9}$ S. R. Schmid, W. R. D. Wilson, Tribology in manufacturing, In: B. Bhushan (Ed.), Modern Tribology Handbook, CRC Press, NY 2000

${ }^{10}$ S. Gulizia, M. Z. Jahedi, Evaluation of PVD coatings for industrial applications, 6th International Tooling Conference, Karlstad, Sweden, 2002, 739-748

${ }^{11}$ Y. Hou, W. Zhang, Z. Yu, S. Li, Selection of tool materials and surface treatments for improved galling performance in sheet metal forming, The International Journal of Advanced Manufacturing Technology, 43 (2009), 1010-1017, doi:10.1007/s00170-008-1780-2 ${ }^{12}$ B. Bhushan, B. K. Gupta, Handbook of Tribology: Materials, Coatings and Surface Treatments, McGraw-Hill, NY 1991

${ }^{13}$ H. Paschke, M. Weber, G. Braeuer, T. Yilkiran, B. A. Behrens, H. Brand, Optimized plasma nitriding processes for efficient wear reduction of forging dies, Archives of Civil and Mechanical Engineering, 12 (2012), 407-412, doi:10.1016/j.acme.2012.06.001

${ }^{14}$ S. J. Bull, R. I. Davidson, E. H. Fisher, A. R. McCabe, A. M. Jones, A simulation test for the selection of coatings and surface treatments for plastics injection moulding machines, Surface and Coatings Technology, 130 (2000), 257-265, doi:10.1016/S0257-8972(00) 00697-6

${ }^{15}$ B. Podgornik, V. Leskovšek, J. Vizintin, Influence of deep-cryogenic treatment on tribological properties of P/M high-speed steel, Materials and Manufacturing Processes, 24 (2009), 734-738, doi:10.1080/ 10426910902809339

${ }^{16}$ B. Podgornik, F. Majdic, V. Leskovsek, J. Vizintin, Improving tribological properties of tool steels through combination of deep-cryogenic treatment and plasma nitriding, Wear, 288 (2012), 88-93, doi:10.1016/j.wear.2011.04.001

${ }^{17}$ K. L. Rutherford, S. J. Bull, E. D. Doyle, I. M. Hutchings, Laboratory characterisation of the wear behaviour of PVD-coated tool steels and correlation with cutting tool performance, Surface and Coatings Technology, 80 (1996), 176-180, doi:10.1016/0257-8972 (95)02706-8

${ }^{18}$ M. Stoiber, M. Panzenbock, C. Mitterer, C. Lugmair, Fatigue properties of Ti-based hard coatings deposited onto tool steels, Surface and Coatings Technology, 142-144 (2001), 117-124, doi:10.1016/ S0257-8972(01)01220-8

${ }^{19}$ B. Podgornik, S. Hogmark, O. Sandberg, V. Leskovsek, Wear resistance and anti-sticking properties of duplex treated forming tool steel, Wear, 254 (2003), 1113-1121, doi:10.1016/S0043-1648(03) 00322-3
${ }^{20}$ V. Imbeni, C. Martini, E. Lanzoni, G. Poli, I. M. Hutchings, Tribological behaviour of multi-layered PVD nitride coatings, Wear, 251 (2001), 997-1002, doi:10.1016/S0043-1648(01)00706-2

${ }^{21}$ J. Heinrichs, S. Jacobson, Mechanisms of Transfer of Aluminium to PVD-Coated Forming Tools, Tribology Letters, 46 (2012), 299-312, doi: $10.1007 / \mathrm{s} 11249-012-9952-5$

${ }^{22}$ C. Donnet, A. Erdemir, Tribology of diamond-like carbon films: Fundamentals and Applications, Springer, 2008

${ }^{23}$ B. Podgornik, J. Vižintin, O. Wänstrand, M. Larsson, S. Hogmark, H. Ronkainen, K. Holmberg, Tribological properties of plasma nitrided and hard coated AISI 4140 steel, Wear, 249 (2001), 254-259, doi:10.1016/S0043-1648(01)00564-6

${ }^{24}$ I. Ebrahimzadeh, F. Ashrafizadeh, High temperature wear and frictional properties of duplex-treated tool steel sliding against a two phase brass, Ceramics International, 40 (2014), 16429-16439, doi:10.1016/j.ceramint.2014.07.151

${ }^{25}$ B. Podgornik, J. Vizintin, S. Hogmark, Improvement in galling performance through surface engineering, Surface Engineering, 22 (2006), 235-238, doi:10.1179/174329406X122946

${ }^{26}$ B. Podgornik, J. Jerina, Surface topography effect on galling resistance of coated and uncoated tool steel, Surface and Coatings Technology, 206 (2012), 2792-2800, doi:10.1016/j.surfcoat.2011.11.041

${ }^{27}$ J. A. Schey, Tribology in Metalworking: Friction, Lubrication and Wear, ASM, Ohio 1984

${ }^{28}$ C. Subramanian, K. N. Strafford, T. P. Wilks, L. P. Ward, On the design of coated systems: metallurgical and other considerations, Journal of Materials Processing Technology, 56 (1996), 385-397, doi:10.1016/0924-0136(95)01852-2

${ }^{29}$ L. Norstrom, B. Johansson, Selection of tool steels for cold-work applications, International Conference on Tooling, Bochum, Germany, 1989, 193-208

${ }^{30}$ A. Gåård, Influence of tool microstructure on galling resistance, Tribology International, 57 (2013), 251-256, doi:10.1016/j.triboint. 2012.08.022

${ }^{31}$ R. Seidel, H. Luig, Friction and wear processes in hot die forging, International Conference on Tooling Materials, Interlaken, Switzerland, 1992, 467-480

${ }^{32}$ O. Barrau, C. Boher, C. Vergne, F. Rezai-Aria, Investigations on friction and wear mechanisms of hot forging tool steels, 6th International Tooling Conference, Karlstad, Sweden, 2002, 81-94

${ }^{33}$ P. Carlsson, M. Olsson, PVD coatings for sheet metal forming processes - a tribological evaluation, Surface and Coatings Technology, 200 (2006), 4654-4663, doi:10.1016/j.surfcoat.2004.10.127

${ }^{34}$ H. Paschke, M. Weber, P. Kaestner, G. Braeuer, Influence of different plasma nitriding treatments on the wear and crack behavior of forging tools evaluated by Rockwell indentation and scratch tests, Surface and Coatings Technology, 205 (2010), 1465-1469, doi: 10.1016/j.surfcoat.2010.07.053

${ }^{35}$ B. Podgornik, J. Vižintin, Galling properties of forming tool steels How to determine and improvements through surface engineering, International Conference on Tribology in Manufacturing Processes, Yokohama, Japan, 2007, 195-202

${ }^{36}$ A. Gåård, R. M. Sarih, Influence of Tool Material and Surface Roughness on Galling Resistance in Sliding Against Austenitic Stainless Steel, Tribology Letters, 46 (2012), 179-185, doi:10.1007/ s11249-012-9934-7

${ }^{37}$ M. Geiger, U. Popp, U. Engel, Excimer Laser Micro Texturing of Cold Forging Tool Surfaces - Influence on Tool Life, Manufacturing Technology, 51 (2002), 231-234, doi:10.1016/S0007-8506(07) 61506-6

${ }^{38}$ T. D. Ling, P. Liu, S. Xiong, D. Grzina, J. Cao, Q. J. Wang, Z. C. Xia, R. Talwar, Surface Texturing of Drill Bits for Adhesion Reduction and Tool Life Enhancement, Tribology Letters, 52 (2013), 113-122, doi:10.1007/s11249-013-0198-7

${ }^{39}$ B. Podgornik, M. Sedlaček, Performance, characterization and design of textured surfaces, Journal of Tribology, 134 (2012), 041701/1-041701/7, doi:10.1115/1.4007108 


\section{B. PODGORNIK, V. LESKOVŠEK: WEAR MECHANISMS AND SURFACE ENGINEERING OF FORMING TOOLS}

${ }^{40}$ L. Lu, Q. M. Wang, B. Z. Chen, Y. C. Ao, D. H. Yu, C. Y. Wang, S. H. Wu, K. H. Kim, Microstructure and cutting performance of CrTiAlN coating for high-speed dry milling, Transactions of Nonferrous Metals Society of China, 24 (2014), 1800-1806, doi:10.1016/ S1003-6326(14)63256-8

${ }^{41}$ B. Podgornik, S. Hogmark, O. Sandberg, Proper coating selection for improved galling performance of forming tool steel, Wear, 261 (2006), 15-21, doi:10.1016/j.wear.2005.09.005

${ }^{42}$ A. Ghiotti, S. Bruschi, Tribological behaviour of DLC coatings for sheet metal forming tools, Wear, 271 (2011), 2454-2458, doi:10.1016/j.wear.2010.12.043

${ }^{43}$ T. Horiuchi, S. Yoshihara, Y. Iriyama, Dry deep drawability of A5052 aluminum alloy sheet with DLC-coating, Wear, 286-287 (2012), 79-83, doi:10.1016/j.wear.2011.07.005

${ }^{44}$ J. Heinrichs, M. Olsson, S. Jacobson, Initiation of Galling in Metal Forming: Differences Between Aluminium and Austenitic Stainless Steel Studied In Situ in the SEM, Tribology Letters, 50 (2013), 431-438, doi:10.1007/s11249-013-0139-5

${ }^{45}$ J. Heinrichs, S. Jacobson, Mechanisms of Transfer of Aluminium to PVD-Coated Forming Tools, Tribology Letters, 46 (2012), 299-312, doi:10.1007/s11249-012-9952-5

${ }^{46} \mathrm{G}$. Hakansson, Experiences of surface coated tools, International Conference on Recent Advances in Manufacture \& Use of Tools \& Dies and Stamping of Steel Sheets, Olofstrom, Sweden, 2004, 245-254

${ }^{47}$ B. Podgornik, J. Vižintin, V. Leskovšek, O. Wänstrand, M. Larsson, S. Hogmark, Wear properties of plasma nitrided and hard coated 42CrMo4 steel, Mater. Tehnol., 34 (2000) 1-2, 17-21

${ }^{48}$ B. Podgornik, B. Zajec, N. Bay, J. Vižintin, Application of hard coatings for blanking and piercing tools, Wear, 270 (2011), 850-856, doi:10.1016/j.wear.2011.02.013

${ }^{49}$ P. Jurči, B. Šuštaršič, V. Leskovšek, Fracture characteristics of the Cr-V ledeburitic steel Vanadis 6, Mater. Tehnol., 44 (2010) 2, 77-84

${ }^{50}$ P. Karlsson, A. Gåård, P. Krakhmalev, Influence of tool stee microstructure on friction and initial material transfer, Wear, 319 (2014), 12-18, doi:10.1016/j.wear.2014.07.002
${ }^{51}$ B. Podgornik, M. Sedlaček, V. Leskovšek, Surface engineering of fine blanking tool inserts, Project report, Institute of Metals and Technology, Ljubljana, 2014

${ }^{52}$ B. Podgornik, V. Leskovšek, B. Arh, The effect of heat treatment on the mechanical, tribological and load-carrying properties of PACVD-coated tool steel, Surface and Coatings Technology, 232 (2013), 528-534, doi:10.1016/j.surfcoat.2013.06.019

${ }^{53}$ B. Podgornik, V. Leskovšek, F. Tehovnik, J. Burja, Vacuum heat treatment optimization for improved load carrying capacity and wear properties of surface engineered hot work tool steel, Surface and Coatings Technology, 261 (2015), 253-261, doi:10.1016/j.surfcoat. 2014.11.021

${ }^{54}$ M. Çöl, D. Kir, E. Erişir, Wear and blanking performance of AlCrN PVD-coated punches, Materials Science, 48 (2013), 514-520

${ }^{55}$ M. Bayramoglu, H. Polat, N. Geren, Cost and performance evaluation of different surface treated dies for hot forging process, Journal of Materials Processing Technology, 205 (2008), 394-403, doi:10.1016/j.jmatprotec.2007.11.256

${ }^{56}$ V. Leskovšek, B. Podgornik, M. Jenko, A PACVD duplex coating for hot-forging applications, Wear, 266 (2009), 453-460, doi:10.1016/ j.wear.2008.04.016

${ }^{57}$ E. Doege, E. Westkamper, R. Seidel, C. Romanowski, G. Andreis, O. Morlok, Combined surface treatment of forging tools by plasma nitriding and PACVD, Progress in tool steels, Bochum, Germany, 1996, 373-384

${ }^{58}$ P. Panjan, I. Urankar, B. Navinšek, M. Terčelj, R. Turk, M. Čekada, V. Leskovšek, Improvement of hot forging tools with duplex treatment, Surface and Coatings Technology, 151-152 (2002), 505-509, doi:10.1016/S0257-8972(01)01634-6

${ }^{59}$ V. Leskovšek, B. Podgornik, Multi-functional KIc-test specimen for the assessment of different tool- and high-speed-steel properties, Mater. Tehnol., 47 (2013) 3, 273-283 